\title{
El alhajamiento de las imágenes marianas españolas: los joyeros de Guadalupe de Cáceres y el Pilar de Zaragoza
}

La historia de las imágenes marianas en España, concretamente las figuradas en esculturas de bulto redondo, alcanza venerable antigüedad, pues, si bien no son demostrables ciertas leyendas piadosas que pretenden hacerlas proceder de los primeros tiempos del cristianismo, existen algunas imágenes que constatan un floreciente culto en el ámbito románico.

La costumbre de añadir costosas telas para mejor lucimiento de tales simulacros es asimismo muy antigua. Suponemos que empezaría por la colocación de mantos y otras piezas sueltas de ricos textiles, que se donarían para poder enriquecer la imagen en días señalados, logrando contrastes entre los chapeados metálicos, por lo general de plata, o las policromías que las recubrían y la suave blandura de las sedas. Se desprende de los antiguos inventarios, como el de la Virgen de Lluc ${ }^{1}$, que ya por el siglo XIV era uso común vestir y alhajar las imágenes marianas ${ }^{2}$.

Paralelamente a las donaciones de textiles se entregarían alhajas diversas. Tradicionalmente fueron los exvotos más comunes las lámparas de luz perpetua con sus correspondientes dotaciones, pero su costo no estaba al alcance de todos. Y, por otra parte, es lógico que surgiera el deseo de ubicar cada ofrenda lo más cerca posible de la imagen que es la que, al fin y al cabo, posee poderes profilácticos.

$\mathrm{Si}$ algo define el estatus de una familia, su procedencia y estilo, son las joyas. Su valor social es superior al crematístico y suelen preservarse hasta el momento de una necesidad perentoria, a modo de rudimentario seguro. Estos objetos son quizás lo más apreciado por el grupo familiar, y la persona que las ofrece a una imagen de su devoción se verá privada de su uso. Por ello, el tratamiento que reciban por parte de la autoridad eclesiástica debe ser exquisito, pues son producto de un desprendimiento que vá más allá del valor material y así lo comprende el código de Derecho Canónico.

"Primer inventari de la capella de Santa María de Lluc any 1395", en Comunicació Lluch (Mallorca: Santuari de Lluch, 1992), 20 pp. S.m.d.

2 Para la mejor comprensión del fenómeno, consúltese: Antonio CEA GuTiÉRrez, Religiosidad popular. Imágenes vestideras (Zamora, 1992). 
En primer lugar, el deseo de todo devoto es que la joya permanezca, como hemos dicho, lo más cerca posible de la imagen, llegándose a aceptar, para ello, que sea enviada al crisol o desmontada (con la subsiguiente pérdida de su aspecto, y de su valor histórico y artístico, si lo tiene) para realizar coronas, cetros, halos o cualquier elemento de los que normalmente constituyen el ornato fijo de las imágenes marianas en España.

La costumbre de coronar canónicamente las imágenes de mayor devoción ha sido causa de la reconversión de una ingente cantidad de alhajas de todo tipo, pérdida irreparable para la historia de la joyería antigua española, pero comprensible desde la óptica de la piedad popular. Esta contraposición de intereses puede ayudar a explicar el hecho de que el estudio de la joyería española no haya sido apenas iniciado, puesto que los ejemplares exhibidos en colecciones públicas y privadas representan un escaso número frente al contenido de los joyeros marianos que aún existen, diseminados por toda España, donde, además, la antigüedad de ciertas donaciones garantiza la autenticidad de los ejemplares, cosa que no se puede aseverar de muchas de las piezas que forman parte de las colecciones seculares más conocidas, siempre bajo sospecha, a causa de las hábiles falsificaciones y creaciones historicistas realizadas, sobre todo, a partir del XIX.

Otro aspecto que no se suele considerar es la falta de tratamiento interdisciplinar del tema, ya que los escasos estudiosos interesados en el tema de la orfebrería de oro en España, especialmente la joyería, suelen publicar sus conclusiones de acuerdo con los parámetros habituales de la historiografía artística, tales como autor, época, tipo, material, lo que, en este caso no es suficiente, puesto que no abarcan toda la información que la pieza puede ofrecer, información que, una vez procesada, puede corregir las conclusiones anteriores.

En la vertiente antropológica, las ofrendas de joyas ofrecen el mayor interés, puesto que muchas de ellas vienen a ser donaciones condicionadas, que obligan su afectación al uso de la imagen, so pena de revocar la donación. Esto coloca a los custodios en una situación delicada a la hora de administrar adecuadamente los fondos compuestos por donaciones de este tipo, puesto que, en definitiva, se convierten en guardianes de un conjunto similar al thesaurós griego, el cúmulo de objetos de prestigio que daban fe de la categoría de una divinidad concreta y la importancia de su santuario.

El problema surge cuando la Iglesia Católica ha de conciliar su mensaje evangélico de pobreza con la presencia de estas riquezas acumuladas por el paso del tiempo. El problema no es nuevo y, ya en el siglo $\mathrm{xv}$, Fray Alonso de Oropesa, General de la Orden Jerónima, escribía: “Ytem, 
porque fallamos que muchas personas seglares son escandalisadas cuando ven en nuestros monesterios curiosidades cerca de los ornamentos e paramentos e joyas de plata...", con lo que indicaba la no conveniencia de mostrar los tesoros del monasterio para no provocar contradicciones ni escándalo en los fieles ${ }^{3}$.

Las joyas son, además, objetos fácilmente convertibles en caso de una necesidad, así como especialmente vulnerables al robo, por su valor en relación al tamaño, lo que plantea numerosos problemas para su custodia y exhibición, especialmente cuando no se dispone de las medidas de seguridad suficientes, lo que lleva a mostrarlas exclusivamente cuando es imprescindible según las necesidades del culto. Esto mismo acarrea la desconfianza inicial de sus custodios hacia cualquiera que pretenda estudiarlas, lo que dificulta su conocimiento y accesibilidad.

A lo largo del presente siglo, especialmente hacia los años sesenta y setenta, muchas imágenes de valor artístico que era posible contemplar con vestiduras fueron despojadas de éstas, quedando los textiles reducidos al uso de las imágenes "de candelero" o muy mutiladas, que no podían exhibirse sin las vestimentas adecuadas. También las joyas fueron retiradas en su mayoría, perdiendo su uso natural, puesto que no serían, de ninguna manera, colocadas sobre la imagen. Curiosamente, empero, no han disminuido las donaciones de alhajas, lo que prueba el deseo de establecer, por parte del donante, lazos sobrenaturales con la imagen, al entregar algo que está, en principio, reservado al uso de los miembros de la propia familia.

Con el tiempo, olvidada la razón de tales ofrendas, las instituciones eclesiásticas parecen haber sentido una cierta sensación de culpabilidad, lo que se traduce en el deseo de deshacerse de las joyas - en las que se suele ver, por falta de conocimientos sobre las mismas, únicamente su valor monetario- o al menos, alejarlas de la vista de los fieles. A esto se añade el espíritu de simplicidad promovido por el último Concilio, y la desconfianza hacia las manifestaciones de la piedad popular, alejada a veces de las creencias ortodoxas.

Con el fin de proporcionar una somera idea del interés que pueden encerrar - para antropólogos e historiadores del arte- los joyeros marianos españoles, por su acumulación de alhajas como ofrendas y exvotos, elegimos dos ejemplos de singular importancia: el correspondiente a Santa María de Guadalupe, en Cáceres, y el de N. ${ }^{a}$ S. ${ }^{a}$ del Pilar de Zaragoza, advocaciones ligadas a la historia de España.

3 Sebastián García y Felipe TRENADO, O.F.M., Guadalupe, Historia, devoción y arte (Sevilla, 1978), p. 512. 
El primero centra nuestro interés en la existencia de un inventario gráfico del joyero, realizado ya en plena decadencia del Monasterio, y, sin embargo esplendoroso por el contenido que describe. Las alhajas han desaparecido, pero el interés puesto en su día por preservar la memoria de las donaciones ha permitido que los datos del conjunto hayan llegado hasta nosotros como si aún existiera físicamente. Este es un ejemplo claro de cómo el análisis y conocimiento, no sólo no perjudica, sino que beneficia la seguridad, haciendo más difíciles los robos y desapariciones, otorga el valor real a cada objeto, y evita las argucias de los desaprensivos ante el desconocimiento de la joyería histórica, a la vez que conserva la memoria de la importancia de cada santuario. Además, la comprensión del fenómeno de las ofrendas, y de la aportación de cada alhaja concreta a la Historia del Arte y la Cultura, impide que se las vea como objetos simplemente valiosos o estéticos, prioritariamente fungibles.

El segundo ejemplo, no menos importante, plantea la situación contraria: abundan las piezas supervivientes, pero escasea la documentación antigua, relativa a éstas. Se trata del joyero del Pilar de Zaragoza, santuario, también, básico de la piedad española, que se mantiene muy viva en torno a la pequeña imagen titular.

Además de lo que se conserva en Zaragoza, el Museo Victoria y Alberto, en Londres, expone un importante conjunto adquirido en 1870 , con ocasión de una subasta realizada para sufragar las obras de finalización de la basílica, por lo que, atendiendo al número de joyas que se conocen, quizás sea el del Pilar el más completo y rico de los joyeros marianos españoles.

\section{El JOYEL DE GuADALUPE}

A juzgar por los documentos, el joyel de Guadalupe tiene trazas de haber sido, si no el primero, sí uno de los mas importantes de España, en número y calidad de piezas. Ya se ha comentado arriba cómo, en el siglo XV, fray Alonso de Oropesa, General de la Orden, recomienda restringir el acceso a la visita y contemplación de estos tesoros "...ca somos çertificados que dello ha nasçido e nasçe grand escandalo e materia de murmuraçion...." ${ }^{4}$.

El Monasterio guarda memoria de sus bienhechores de diversas maneras. Las tablas de donantes, clasificadas según categorías sociales, fueron

- Rótulo de Capítulos Generales y privados y autos de Visita del Monasterio de Guadalupe, Archivo Real Monasterio Sta. M." de Guadalupe, Carp. I, VI, citado por Sebastián García y Felipe Trenado, op. cit., p. 512. 
retiradas de los claustros y copiadas en 1664 por mandato del Prior fray Gerónimo de Ciudad Real. Abundan los libros de cuentas y estado de la sacristía, inventarios de lámparas, libros de bienhechores, así como lo consignado por los antiguos historiadores jerónimos del Monasterio, como los priores Talavera o San Joseph, seguidos por los estudiosos de la Orden Franciscana, custodios actuales del monasterio, entre los que destacan Villacampa, Correa y Álvarez, Rubio, García y Trenado, etc. Esto sin contar los estudios que sobre distintos aspectos han realizado los especialistas en Historia del Arte ${ }^{5}$.

En lo que respecta a las alhajas que tuvo el monasterio, consideramos fundamentales tres de los códices conservados en su archivo: el núm. 87, Libro relación de bienbechores de Guadalupe, comprendiendo reyes, príncipes, personajes..., y el códice 90, Libro de las capellanías, lámparas y bienbechores, que incluye la transcripción de las viejas tablas. Especialmente notable por sus dibujos es el códice 83, Descripción de las albajas de la Virgen de Guadalupe, con noticias bistóricas, del que se tratará extensamente.

La lista de donantes podría hacerse interminable, dado que, desde el siglo $\mathrm{XV}$, Guadalupe estaba incluido en las llamadas mandas forzosas, que debían recoger obligatoriamente en su testamento los miembros de las clases sociales acomodadas. Esto concernía tanto a España como sus reinos y fue práctica común hasta finales del siglo XVIII. Las mandas eran cuatro y debían otorgarse en cada testamento a favor de Roma, Jerusalén, Santiago de Compostela y Guadalupe.

Además, desde muy antiguo constan donaciones reales. Fray Diego de Écija ${ }^{6}$ relata la llegada de Alfonso XI a Guadalupe tras la victoria de El Salado, y puntualiza que dejó buena parte del botín de oro, plata, joyas y otras riquezas para el ornato del templo. (El Padre San Joseph recoge similar narración) ${ }^{7}$.

5 Entre la bibliografía empleada, además de la obra citada en la nota 3, destacamos las siguientes publicaciones: Carlos CALLEJO, El Monasterio de Guadalupe (Madrid, 1958); Fr. Germán RuBIO, Historia de Nuestra Señora de Guadalupe (Barcelona, 1926); E. SARrablo, E. Correa y A. Álvarez, Inventario del Archivo de Nuestra Señora de Guadalupe (Madrid, 1958); P. Carlos G. VillaCAMPA, Grandezas de Guadalupe (Madrid, 1924).

6 Véase Fray Diego de ÉcIJA, Libro de la invención de esta Santa Imagen de Guadalupe; $y$ de la erección y fundación deste Monasterio, y de algunas cosas particulares y vidas de algunos religiosos de él (Edición y notas de F. Arcángel Barrado, Cáceres, 1953).

7 Ver Fray Diego de ÉCIJA, op. cit., cf. Francisco de SAN JOSEPH, Historia universal de Nuestra Señora de Guadalupe (Madrid, 1743). 
La Corte itinerante de los Reyes Católicos se estableció en el Monasterio al menos en una veintena de ocasiones, pese a lo apartado del lugar, y no escasearon las ofrendas.

Felipe II fue magnánimo con el Monasterio y de entre sus regalos sobresale, por haberse conservado, el elegante escritorio damasquinado que, labrado en Roma por Juan Glamín en 1565, donó para que sirviera de sagrario. En agradecimiento por la rogativa para pedir la salud del príncipe Carlos, envió asimismo una lámpara de plata. En 1588 fueron diamantes, rubíes, esmeraldas y perlas su regalo, para reparar el llamado "Manto Rico de la Comunidad", fabuloso ejemplar, a medio camino entre la orfebrería y el textil. Su diseño son dos grandes anagramas de María, con dos escudos de oro esmaltados de colores, enriquecidos con grandes perlas, posiblemente parte de las que donara el Rey.

Isabel Clara Eugenia, su hija predilecta, hizo llegar desde Flandes un célebre vestido que una tradición sin fundamento supone bordado por sus manos. En el Libro de Bienhechores ${ }^{8}$ se especifica que se envió esta indumentaria desde Flandes. Sobre su rico bordado, se había aplicado una guarnición de 71 piezas grandes y 65 pequeñas, además de 1.221 perlas. Las piezas, labradas en oro, llevan engastado en el centro un diamante punta, con cuatro perlas, formando una cruz las grandes, y dos a cada extremo más pequeñas. Ambos mantos continúan en uso para el ornato de la Virgen y constituyen - tras la desaparición en 1936 del llamado Manto de las Ochenta Mil Perlas, perteneciente a la Virgen del Sagrario, Patrona de Toledo ${ }^{-}$-, uno de los más extraordinarios ejemplos del patrimonio textil español.

También otro valioso manto, el llamado "viejo de la Comunidad", se enriqueció con similares guarniciones, pues en 1552, fray Alejo, platero del Monasterio, realizó sus numerosos joyeles, ornados también con diamantes y perlas.

Don Juan de Austria, hijo ilegítimo de Felipe IV, fue uno de los grandes protectores del Monasterio, y realizó numerosas e importantes

8 Libro de bienhechores, ff. 26 y 27.

9 Este manto, y las demás piezas a juego para el adorno de la magnífica Imagen, obra datada en el siglo xiII, de la Virgen del Sagrario, patrona de Toledo y el Niño Jesús que le acompaña, se tuvieron por textiles de valor excepcional, y se han descrito en numerosos comentarios sobre Toledo, además de existir buena documentación sobre su elaboración, transformaciones y los elementos que lo componen, entre ellos, las numerosas joyas que la piedad de destacados personajes entregó para ser superpuestas a los vestidos, ya de por sí magníficos, especialmente por la calidad de las perlas con que estaban bordados, y por su número, que cubría materialmente el tisú de plata que formaba el fondo. Ver Sixto RAMÓn PARRo, Toledo en la mano, Ed. facs. de la de 1857 (Toledo, 1978), I, pp. 571-585. 
donaciones de candelería y otras piezas de plata, además de muy valiosas joyas, como la que donó en 1647, sortija compuesta por una esmeralda grande y 12 diamantes alrededor, que, según el Padre San Joseph, se puso al frente de una de las coronas de oro de la imagen titular. Pero más importante fue la donación de 1664: una venera de oro y rubíes, con la Encomienda de San Juan, orden de la que era prior.

Si nos referimos a la nobleza, alta y baja, la lista se haría interminable: Duques de Alba, de Uceda, de Béjar, de Gandía, de Abrantes, de Nájera; Marqueses de Leganés, de Villamaina, del Valle, Sofraga, Torre Orgaz, Mejorada... Condes como los del Puerto, La Coruña, Oropesa, Siruela, Villaviciosa; obispos, arzobispos, nuncios, cardenales y virreyes. Altos funcionarios, poderosos e hidalgos compiten con la generosidad de simples vecinos y gentes del estado llano, para quienes la devoción no está relacionada con la política. No faltan en la relación celebridades, como Cervantes, Santa Teresa, San Juan de Dios, Cisneros. Las donaciones anónimas son masivas. Todas las clases sociales asisten como donantes a Guadalupe, en incesante desfile.

Otro aspecto capital de esta confluencia es la especial relación de Guadalupe con América. Recordemos la obligatoriedad de las mandas por un lado, y, por otro, la expansión del culto a la advocación como patrona de los conquistadores extremeños. El análisis de esta circunstancia nos permitirá contemplar los dibujos del Inventario del Joyel con doble perspectiva, preguntádonos si, en algunos casos, nos encontramos ante manufacturas indianas, e, incluso, ante productos traídos de las Indias Orientales, a través de las líneas marítimas de la Costa Este.

Casi todos los cronistas guadalupenses se han ocupado de las visitas que realizara al santuario Cristóbal Colón, su voto, de la imposición del nombre de Guadalupe a una de las islas por él descubiertas, del bautizo de sus criados y, por último, de sus presentes al Monasterio. Demetrio Ramos, en su artículo "Las visitas de Colón a Guadalupe y el cumplimiento del voto del viaje de retorno" ${ }^{10}$, cita el testimonio de Münzer, quien en 1495 vió en las estancias del Monasterio papagayos vivos y objetos de plumas que se consideraban traídos por el Almirante ${ }^{11}$. Una nota de Fray José de Alcalá puntualiza que, en 1496, al ser bautizados sus criados, Colón ofreció dos lámparas de plata y varias joyas de oro ${ }^{12}$. Esta sería la única visita históricamente comprobada de Colón, no pasando de ser meras suposiciones el resto.

10 Guadalupe, núm. 674-675 (1985).

11 Jerónimo MÜNZER, Viaje por España y Portugal 1494-1495 (Madrid, 1951).

12 Archivo del Real Monasterio de Nuestra Señora de Guadalupe, legajo 14, f. 34. 
Más relevantes son las relaciones de Hernán Cortés con el Monasterio. Ya el Padre Talavera menciona diversas donaciones, entre ellas trabajos de arte plumario, lámparas y alhajas.

Efectivamente, el ya citado Libro de las capellanias, lámparas y bienbechores, relata la visita en estos términos: "El Marqués del Valle de Guaxaca, en las Indias de la Nueva España, Don Fernando Cortes, Capitan General de la Nueva España, vino de las Indias a visitar esta Santa Casa el año de 1528, y ofrecio a Nuestra Señora un rico alacran de oro, hecho de manos de indios y tiene una esmeralda de mucho valor y ofrecio otras cosas de plumas hechas.....

En el códice del Joyel se halla dibujada una alhaja que se identifica con la descrita mediante una nota, en la que se narra, además, un milagro acaecido al donante y relacionado con la forma de aquélla. Ha sido objeto de una larga polémica, que creemos zanjada con nuestro reciente trabajo sobre el tema, al que remitimos ${ }^{13}$ (Fig. 1).

Funcionarios, clero, militares y simples vecinos enviaban dinero, piedras preciosas, perlas, lámparas y diversos objetos desde América. Sólo entre 1548 y 1558, las entradas alcanzaron la suma extraordinaria de 30 millones de maravedies ${ }^{14}$. Las nueve décimas partes del fabuloso tesoro acumulado con el paso de los siglos desaparecieron en los avatares padecidos por el monasterio entre 1808 y 1876, a lo largo de buena parte del siglo XIX.

Aparte de las lámparas, habitual donación, consta la procedencia indiana de diversos objetos realizados en metales preciosos; así, Álvaro de Torres envió una campanilla de oro; Don Fadrique de Tole-

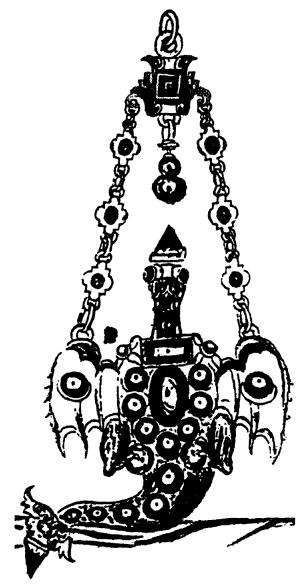

FIG. 1.-Este pinjante de cadenas en forma de dragón, obra típica del último tercio del siglo xvI y principios del s. XvII, ha sido considerado ofrenda de Hernán Cortés en 1528 , tejiendo toda una leyenda para justificar su adscripción.

13 Recientemente hemos analizado la formación de la pía tradición a la que hace referencia el texto (una venenosa picadura curada milagrosamente), nacida de la presencia real del personaje en el santuario, como donante, pero no vinculado al ofrecimiento de un exvoto. Sobre este tema, véase Letizia ARBETETA MirA, "El exvoto de Hernán Cortés", en Exvotos, catálogo de la exposición del mismo nombre (México, 1996), en prensa.

${ }_{14}$ Véanse los datos que, al respecto, proporciona Fray Germán RuBIO, Historia de Nuestra Señora de Guadalupe (Barcelona, 1926). 
do, Capitán General de la Armada, ofreció dos facistoles de plata, de muy rica hechura, que pesaron ciento cuarenta y dos marcos y cuatro onzas. Tiene interés iconográfico el envío que desde México realizó doña Mariana Ybarra de Velasco, que consistía en una luna de plata blanca para los pies y un sol de oro para la cabeza de la imagen titular. También curiosa es la dádiva de Don Francisco de Toledo, Virrey de Perú, formada por tres figuras de plata de los Reyes Magos. Su secretario ofreció en 1619 un trono de plata para la Virgen, y también desde Lima, en 1642, un devoto extremeño envía candeleros de plata.

En cuanto a las joyas, de la interminable relación entresacamos aquellas cuya descripción coincide con algunas dibujadas en el Libro de las Albajas: un papagayo de oro esmaltado de verde y con diamantes, regalado en una visita de 5 de octubre de 1594 de Doña Mencía de la Cerda, Marquesa del Valle, la misma que donó el vestido arriba reseñado; una piña de ámbar guarnecida de oro, con cadenas, ofrecida en 1591 por el hijo del Virrey de Nueva España; la cruz de cristal y el crucifijo entregados por un Oidor de la Audiencia Real de Lima; la cadena con una imagen de la Concepción que desde Cartagena de Indias se envía en 1606, o la más valiosa joya donada en 1648 por el Corregidor de México, que, realizada con rubíes, formaba el jeroglífico $S$ - clavo, tan caro a la piedad barroca, y del que han sobrevivido varios ejemplos, reflejados en los dibujos de exámenes de platería ${ }^{15}$.

Las joyas, no hay que olvidarlo, tenían un subido valor real, no siempre fácil de transformar. Así, entre la documentación consultada en el Archivo Histórico Nacional encontramos, en el Libro de Actas Capitulares de Guadalupe, noticias como las que siguen: "...Que se le entregue una sortija de un prexioso diamante, que dio el exmo. Sor. Duque de Veraguas para gastos de la Comunidad y otras sortixas y joyas las que dixesse y declarasse $\mathrm{fr} . \mathrm{Al}^{\circ}$ de Madrid platero, que no eran á proposito, para el arreo y prendido de nra. Sra." ${ }^{16}$.

Las variaciones, propias de la vida y transformación del Monasterio, se reflejan asimismo en las rentas donde constan como ingresos las ventas de plata y oro, con cifras importantes en los siglos XVI y XVII, que pudieran incluir

15 Estas citas se han extraído en su mayor parte del artículo de Carlos G. VILLACAMPA, O.F.M. titulado "Generosidad y gratitud de los españoles residentes en Indias durante los siglos XVI y xVII, con Santa María de Guadalupe en Españan, Guadalupe, 671, julio-agosto (1984), pp. 159-167, y bastan para demostrar el incesante flujo de objetos que recalaban en el Joyel de Guadalupe procedentes de Ultramar. En el citado artículo, el autor ha extraído numerosos asientos referentes a donaciones de personas naturales o residentes en Indias, que se consignan en el manuscrito ya citado, titulado Libro de Bienhechores, signatura C-90 del Archivo del Real Monasterio.

16 Ff. $89 \mathrm{v}$ y $90 \mathrm{r}$. 
el excedente de fundiciones periódicas. Como sabemos, el Real Monasterio tuvo un taller propio de platería, que podría vender parte de su producción, especialmente medallas, cuya fabricación se halla documentada desde el siglo XVII y debió ser muy productiva, pues el Monasterio guardaba celosamente la exclusiva de la reproducción de la imagen, tanto en efigie como en estampa ${ }^{17}$. Otra obra importante, la del camarín, necesitó ser costeada, en 1687 , mediante una venta de joyas y plata labrada para recaudar parte de los fondos. En algunas ocasiones, el deseo de la propia Comunidad de enriquecer el equipo de servicio de la imagen titular llevó a sacrificar numerosas joyas antiguas, como en el caso de los importantes cetro y corona, que se emplearon en su ornato durante los siglos Xvil y xviII.

De entre los despojos y mermas sufridos por el Monasterio, destaca la orden de entrega - durante la Guerra de la Independencia, en 1809, a requerimiento de la junta de Badajoz- de las alhajas de oro y plata que quedaban ${ }^{18}$. D. Francisco Borda, comisionado del Rey José Bonaparte, retiró valiosas alhajas, entre ellas una corona muy rica de la Virgen y dos pectorales de gran valor. Algo, no obstante, se pudo enviar a Sevilla, y de ello, al volver Fernando VII, se recuperaron joyas de plata y oro que habían sido trasladadas a Cádiz.

Tal estado de cosas se refleja en una nota dirigida por Fray Alonso de Siruela al nuevo Padre Sacristán F. Miguel de San Martín, en 1815: «...El grandioso e inestimable joyel o tesoro de Ntra. Sra., que ella sola había juntado en el transcurso de cuatro siglos, se armaron las manos de muchos, y en pocos años, le despojaron...." ${ }^{19}$.

Nada supone todo lo referido, en cuanto a cantidad de alhajas deshechas, si se compara con la corona que Félix Granda realizó en 1928 para la coronación canónica de la imagen: se emplearon en su montura 34.364 piedras preciosas obtenidas en parte de joyas donadas por los devotos.

\section{El Códice 83 del ARChivo del Real Monasterio de Santa María DE GuAdaluPe}

De entre los antiguos inventarios del joyel, destaca un códice, existente en el Archivo del Real Monasterio, sin título, que es citado por Sarrablo, Correa y Álvarez como Descripción de las albajas de la Virgen de Guadalupe, con noticias bistóricas (C-83). Es de tamaño folio mayor,

17 Trata del tema de la fabricación de medallas el Libro 1578 de la sección Clero del Archivo Histórico Nacional.

18 Fray Germán RuBIO, op. cit., p. 191.

19 Ibid., p. 195. 
toscamente encuadernado, sin portada. Contiene tres hojas más 48 folios, faltando el folio 40. A esto se añade una hoja inacabada y otra sin numerar, con un dibujo del rostrillo realizado en 1968.

En la introducción previa se relata cómo, al intentar anotar en los libros de caja la razón del paradero de las joyas que se iban a deshacer para guarnecer el viril del nuevo tabernáculo, resultó ser esta una operación complicada, pues no se contaba con descripciones suficientes. De esta situación surgió la idea de realizar un inventario gráfico, dibujando las joyas que aún restaban, inventario que los sacristanes mayores debían cumplimentar en iguales términos con las nuevas donaciones, incluyendo siempre el dibujo, aunque se hiciera una buena descripción y se tomaran los datos del donante ${ }^{20}$.

Según la nota explicativa, la elaboración del códice comenzó en 1778 y fue interrumpida desde el mismo año hasta 1783, fecha probable de su conclusión, si no fue al año siguiente.

La formación del joyel de Guadalupe se deduce de la propia historia del Monasterio, de cuyos donantes principales se ha tratado más arriba. Pero el incremento no es lineal, sino que sufre épocas de retroceso por transformaciones y pérdidas.

Así, el ánonimo prologuista del códice, se expresa en estos términos: "Está reducido [el joyel] a mitad de lo que sería, si las joyas permaneciesen conforme las ofrecieron los devotos en su misma figura y dibujo".

Explica después cómo se fueron deshaciendo las alhajas, previo consentimiento de la Comunidad, para colocar su pedrería en otras piezas tales como el cetro, los pectorales ricos, o el nuevo viril del tabernáculo para el que "cuarenta de las más ricas" proporcionaron cerca de cinco mil piedras, entre ellas un airón o aderezo para el cabello donado en el siglo XVII por una duquesa de Alba. La práctica de aprovechar piedras de otras joyas, desmontándolas, ha llegado hasta hoy, pues en el texto correspondiente al último dibujo del códice, el rostrillo realizado en 1968, se advierte que "Esta alhaja se ha hecho en su mayor parte con piedras procedentes de las joyas legadas a la Sma. Virgen en su testamento por Don Manuel de Ovando y López de Ayala, otras de la familia Barrantes y otras sacadas del joyel general de la Virgen".

A veces, la joya se salva de la destrucción al ser colocada en otra pieza mayor, bien sea entera o parcialmente, tal y como sucede con algunas guarni-

20 En 1995, como trabajo de investigación previo a la elaboración de la tesis doctoral, presentamos el estudio «Guadalupe, Joyel de dos mundos, análisis crítico del códice denominado Joyel de Guadalupe , 280 pp. y numerosas ilustraciones, al que remitimos para más detalles sobre autor, fechas y otros aspectos. (Ejemplares reprografiados en el Departamento de Historia del Arte Moderno II, fac. Geografía e Historia, Univ. Complutense de Madrid). 


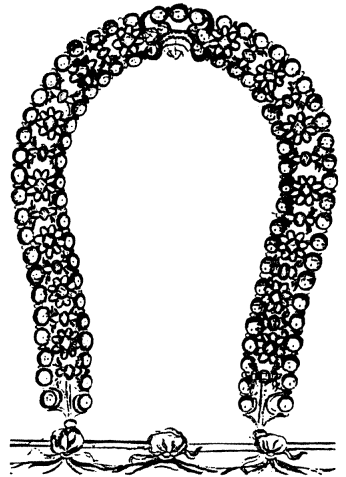

FIG. 2.-Rostrillo del Conde de la Roca. Dibujado en el folio $26 \mathrm{v}$ del códice, este rostrillo, con perlas finas y rosetas de oro con diamantes, se coloca a la Imagen titular el día de su festividad, desde su donación por el Conde de la Roca en 1738.

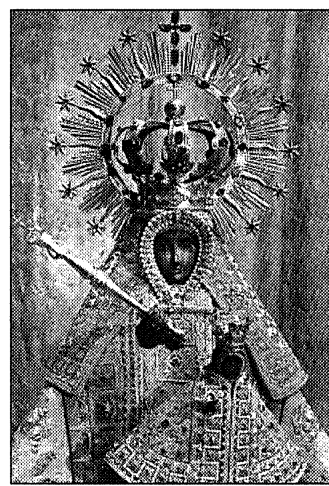

FIG. 3.-Nuestra Señora de Guadalupe, ataviada con el manto y sayo "de la Infanta" y el rostrillo donado por el Conde de la Roca, con el gran diamante que un Consejero de Indias entregó en 1749. ciones metálicas de textiles ricos, como ya se ha visto, o con la sortija del "famoso diamante" que el nuncio Sabas Millini regaló a la imagen y que se colocó en el cetro realizado por la Comunidad en 1680, para el que se deshicieron numerosas joyas. Es de suponer que, en este caso, primó el prestigio del donante antes que el valor de la joya en sí. (Otra sortija, esta con grandes diamantes, donada en 1749 por un Consejero de Indias, se colocó en el frente del rostrillo que más abajo se comenta).

El cambio de uso de una joya puede suponer su preservación: En el fol. $4 \mathrm{v}$ del códice se indica cómo un anillo con una esmeralda grande sirve de manilla o pulsera en la muñeca del Niño.

En efecto, el acomodo o no al ornato de las imágenes condiciona la selección o eliminación de elementos pertenecientes al mismo conjunto, como sucede con el obsequio de los Marqueses de Sofraga, un aderezo adquirido en Barcelona en 1756. De las piezas que lo componían se reserva el peto y la cruz de pescuezo, mientras que las pulseras, los pendientes y el ramo para tocado de los cabellos "...como menos utiles al adorno que usa esta Santa Imagen se deshicieron y colocaron las piedras en el viril del nuebo Tabernaculo...".

Físicamente apenas queda nada, si exceptuamos el rostrillo que se hizo de un collar donado en 1738 por el Conde de la Roca (fol. 26r.), visible en algunas fotografías recientes de la Virgen ${ }^{21}$ (Figs. 2 y 3), que, desde la época de su donación, luce en las festividades.

21 Collar rígido, en forma de herradura, formado por una montura calada de plata dorada, a modo de enrejado, sobre el que se superponen catorce florecillas de oro con nueve diamantes cada una, alternadas con lacitos de oro con tres diamantes. A los extremos, dos hileras con 91 perlas finas, muy iguales en tamaño y color. En la parte central se colocó un anillo donado en 1749 , que se cita más arriba. 
No obstante, es posible encontrar joyas muy similares a las dibujadas en el códice, la mayor parte de ellas pertenecientes a joyeros marianos. Los diseños gráficos de los exámenes de platería de cada época, así como la documentación que es posible obtener acerca de las piezas utilizadas como paralelo, incluidas las representaciones pictóricas, nos informan con exactitud de su cronología.

En el aspecto puramente

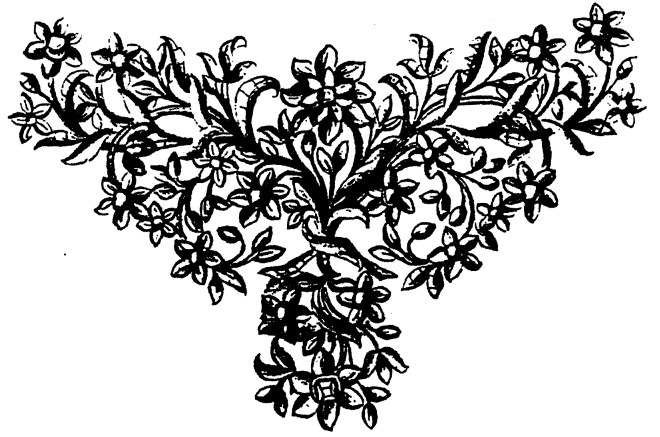

Fig. 4.-Joya cordobesa de plata, rubíes y diamantes, regalo de bodas, que D." Josefa de Góngora Armenta y Godoy ofreció en 1781, por haberla prometido si su hijo llegaba a la edad de quince años. antropológico, los comenta-

rios del inventario contienen datos especialmente valiosos para la historia del exvoto. Dejando aparte la supuesta alhaja de Hernán Cortés, hay constancia de exvotos formales. Así, la joya ofrecida por Doña Josefa de Góngora Armenta y Godoy (fol. $42 \mathrm{v} .^{\circ}$ ), quien acudió al santuario con su marido y un niño de pecho, su hijo. Doña Josefa prometió entregar a la Virgen la joya que su marido le regaló por su boda el día en que el niño cumpliera quince años, como así se hizo en 1781. Por tanto, el magnífico peto de plata, rubíes y diamantes que se reproduce, se realizó hacia 1767 (Fig. 4).

Por haber sanado de una grave enfermedad, la Marquesa de Sofraga ofrendó un aderezo que ya se ha mencionado, en plata, diamantes y

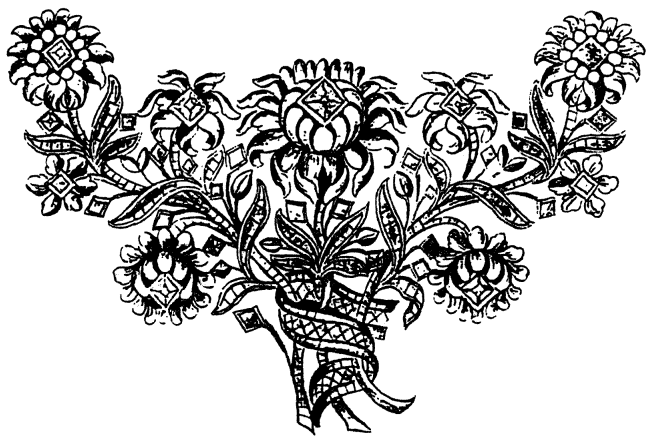

FIG. 5.-Peto o brocamante de diamantes y esmeraldas, parte de un aderezo adquirido en 1756 en Barcelona y ofrecido en 1770 por la Marquesa de Sofraga al sanar su marido de una grave enfermedad. esmeraldas, comprado en Barcelona en 1756, con diseño de motivos florales, que constaba de peto con joya adaptable en forma de cruz (fol. 41 , ns. 1 y 2 ), y pulseras, pendientes, ramo, piocha o airón para la cabeza que se desmontaron. Para dar una idea de su riqueza, las dos piezas que se preservaron tenían 657 diamantes y 219 esmeraldas (Fig. 5).

Otras veces, pese al deseo de recoger los datos del 
donante, éste se niega, como ocurre con la mujer que entregó en 1783 el medio aderezo (prácticamente contemporáneo) representado en el fol. 46r.

En algunos casos, será la memoria tradicional la que vincule una joya con el donante. Así sucede con la supuesta dádiva de la República de Venecia ${ }^{22}$ o el pinjante presentado como donación de Hernán Cortés ${ }^{23}$.

No faltan anécdotas, como el robo de una valiosa cruz, donada por los Duques de Alba, de hacia $1600^{24}$, sustraída de la propia imagen en una festividad y después restituída desde Zaragoza, o el robo de varias piezas, que antes de efectuarse el inventario gráfico nadie pudo precisar cuáles eran.

El inventario del joyel recoge principalmente piezas de oro, soslayando las numerosas donaciones en plata que, sin duda, recibiría la Virgen, y que aún pueden verse en el joyero actual del Monasterio. Las piezas que se reseñan realizadas en plata vienen acompañadas de valiosa pedrería, especialmente las del s. XVIII, en que estuvo de moda este metal. El autor, incluso, se extraña del poco valor que tiene la cruz núm. 1 del fol. 36r., una de las joyas realizadas en plata, lo que nos hace pensar que cualquier pieza no formaría parte del joyel, sino sólo aquellas más selectas, lo que parece responder a la idea de un joyel de uso, en el que se reserva sólo lo mejor. Cierto tipo de piezas tampoco se recogen, siendo presencia obligada en los joyeros marianos españoles: rosarios, bandas, rosas, botones y otras piezas de aplicación al textil, lo que confirma que el códice se plantea como una selección, recogiendo únicamente la joyería propiamente dicha, procedente en su mayor parte de las clases con más poder adquisitivo, como las capas altas del campesinado y burguesía, además de la nobleza.

Debe tenerse asimismo presente la finalidad de la dádiva, que no es otra que el exorno de la imagen titular. Por tanto, las alhajas son, en definitiva, joyas adecuadas al tamaño y las posibilidades de uso de la imagen, realizada en una escala de, más o menos, dos tercios del tamaño natural. Así encontraremos aderezos completos, consistentes por lo general en tocados para el pelo, collar, joya o cruz para adorno del cuello o del escote, pendientes, manillas o pulseras, sortijas...; medios aderezos, esto es, pendientes, adorno del cuello o escote y sortijas; piezas sueltas, sean

22 Núm. 1, f. 19 r.

23 F. 27 r.

2i F. 37v. Pieza muy similar a una cruz que poseyó desde su infançia la infanta Ana Mauricia, hermana de Felipe IV y reina de Francia, según puede comprobarse en el retrato realizado a ambos hermanos por Pantoja de la Cruz en 1607, hoy en Viena. 


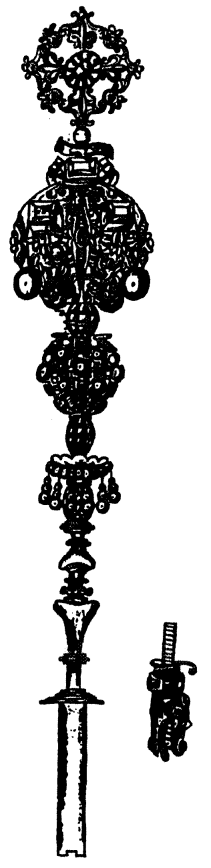

FIG. 6.-Cetro "de la Comunidad", realizado en 1680 para uso cotidiano de la Virgen. Incorpora valiosas joyas, como una sortija donada por el Nuncio Millini, un hábito de la Inquisición y una cabeza de oro esmaltado en el remate. profanas, como los pinjantes de cadenas, religiosas tales como cruces o medallas, o mixtas, como puedan ser las veneras o hábitos, cuya significación social rebasa con mucho su función específicamente religiosa. En algunos casos, el uso propio de la joya se ha adaptado a las necesidades de la imagen, como en los casos ya citados del collar utilizado como rostrillo, o la sortija que sirve de manilla al Niño. En el inventario se consigna, además, el empleo y destino de determinadas joyas, preservadas del crisol, bien a causa de su belleza intrínseca, bien por su especial adecuación a la presentación de la imagen; constan como utilizados el día de su fiesta el cetro dibujado en el folio núm. 2, la calabacilla del fol. 22r. y el rostrillo del fol. 26r., mientras que el peto de esmeraldas y diamantes dibujado en el fol. 11r., unido a la cruz - resto de un aderezodonada por la trujillana D. ${ }^{a}$ Antonia de Orense y Moctezuma, se le colocaba a diario a la imagen, así como el magnífico cetro costeado por la Comunidad en 1680, al que se incorporaron numerosas joyas en todo o parte, como el hábito del Santo Oficio que lo corona, datable hacia los años 50 del s. XVII, la sortija del nuncio Millini, o la cabeza monstruosa del remate, posiblemente centroeuropea, de hacia 1590 (Fig. 6).

De uso cotidiano fueron el llamado rostrillo de diario, dibujado en el fol. $3 v$., realizado en el s. XVIII con dos sartas de gruesas perlas y un fragmento de banda, quizás anterior y el citado anillo o sortija del folio 4 vuelto.

En cuanto a la época de las joyas dibujadas, exceptuando el rostrillo realizado en 1968, el códice abarca ejemplos de la producción de tres siglos: XVI, XVII y XVIII, con ejemplares de diseño en su mayoría españoles. Mientras que es frecuente anotar los nombres de los donantes, la procedencia de las joyas rara vez está indicada, como es el caso de un airón o adorno de la cabeza, que se compró en Córdoba ${ }^{25}$, y el aderezo

25 Núm. 1, f. 12r. 
adquirido en Barcelona que ya hemos comentado. De las circunstancias del donante también puede deducirse el origen de algunas alhajas: así, un vecino de Córdoba, importante centro de producción de orfebrería, es lógico que compre en dicha ciudad sus joyas ${ }^{26}$, y cabe pensar que fue realizado en Portugal el hábito de la Orden de Cristo que ofrecieron en su día los Duques de Béjar ${ }^{27}$. En algún caso se averigua la procedencia por datos contenidos en la propia alhaja, como un relicario firmado en Potosí y fechado en $1626^{28}$.

A juzgar por los dibujos, varias joyas parecen realizadas en las Indias Occidentales y pudiera ser que alguna procediera, por su técnica, de Extremo Oriente. Posiblemente sean centroeuropeos algunos de los pinjantes de cadenas, como el grifo-león núm. 4 del fol. $7 \mathrm{v}$, y el colgante núm. 1 del fol. 45r. En los textos que se acompañan se indican con frecuencia las fechas de donación, pero ello no quiere decir que sean contemporáneas a las de realización de las joyas; es más, hemos advertido un importante desfase entre la época del modelo dibujado y la de su entrega, aplicable en la mayoría de los casos.

Básicamente, las joyas representadas se pueden dividir según su uso, en joyas civiles y joyas devocionales, entendiendo por las primeras aquellas en que predomina el aspecto ornamental y de complemento a la vestimenta, y por las segundas las que ostentan motivos vinculados a la iconografía religiosa. No obstante, en el caso de España, se debe matizar, dada la peculiar característica de sus manifestaciones artísticas, producto y vía de expresión de una sociedad en la que el elemento religioso se introduce profundamente en el vivir cotidiano, diluyendo la frontera antes marcada. Algún tipo concreto de joya, como las llamadas cifras, pueden tener sus versiones laicas o religiosas, según las iniciales representadas sean personales o de nombres sacros, pasando a denominarse, en este caso, con los nombres de estas: Jesús, JHS, IHS, María.

Lo mismo sucede con las cruces o los medallones-relicario, que, desde el siglo XVII suelen añadirse a joyas de varios cuerpos, con las que se pueden combinar, normalmente como extremo inferior, y de las que pueden ser eliminadas, acortando la alhaja (tal y como sucede con los pendientes de varios cuerpos, que se acortan o se alargan según la solemnidad de la ocasión), o bien sustituidas por otro cuerpo a juego.

Nos basamos para la datación de los diseños representados en los dibujos supervivientes de los exámenes de maestría de los plateros en

\footnotetext{
26 F. $42 \mathrm{v}$.

27 F. 34r.

28 Núm. 4, f. $4 \mathrm{v}$.
} 


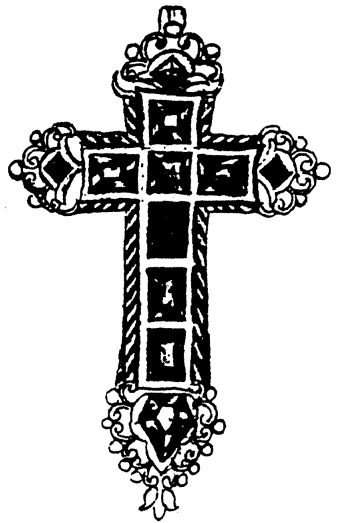

FIG. 7.-Cruz de oro y esmeraldas, de factura americana, entregada por el Obispo de Segovia en 1692. Su dorso tiene dibujos formados por esmalte negro embutido en la masa de oro. distintas ciudades, especialmente Barcelona, de la que se conserva el mayor número conocido de éstos en los ya citados Llibres de Passanties.

De entre las piezas representadas, no siempre recogidos sus modelos en los dibujos de examen, han sobrevivido numerosas ejemplos que se hallan dispersos por museos y colecciones de todo el mundo, estando la mayor parte entre las que la Iglesia Católica posee en España, donadas por los fieles y conservadas en los diversos joyeros de las advocaciones marianas de más devoción (Fig. 7).

Por último, la procedencia social del donante se puede suponer a partir de datos como el coste material de la joya que ofrece, la calidad de su diseño, su temática (por ejemplo, los hábitos, veneras o encomiendas son privativos de las clases nobles), o la relación entre fecha y moda. Por otra parte, hasta el siglo XIX no se produce una separación clara y definitiva de la joyería popular y joyería culta.

\section{El joyero Del Pilar de Zaragoza}

La devoción a María, bajo su advocación popular del Pilar, hace referencia a la tradición de su venida en carne mortal a Zaragoza. Se tienen noticias de su culto en el templo románico erigido en $1146 \mathrm{e}$ incendiado en 1434, al que sustituyó una fábrica gótica, levantada en 1515 y, posteriormente otra barroca, comenzada en 1681 que, muy transformada, es la que hoy conocemos. Tantas obras y avatares tuvieron que afectar a los sucesivos joyeros de alhajas que la devoción acumulaba a los pies de la venerada imagen. A falta de documentación relacionada con este extremo, suponemos que en el incendio de 1434 perecieron buena parte de las joyas; fundiciones, cambios de uso y ventas para costear necesidades urgentes mermaron, con el correr de los tiempos, el caudal que nunca dejó de fluir. Curiosamente, los horrores de la guerra de la Independencia no impideron que buena parte de las joyas se preservara, lo que da idea del aprecio que los zaragozanos tenían al tesoro de su patrona. Existe un inventario del año 1783, prácticamente 
inédito ${ }^{29}$, titulado Imbentario de las alhajas de oro, plata y pedrería ecsistentes en el Sto. templo metropolitano de Nuestra Señora del Pilar de $Z_{\text {Zaragoza }}{ }^{30}$. En él se reconocen descripciones que corresponden a piezas subastadas en 1870, cuyo catálogo se comenta más abajo. Esta venta despertó una gran curiosidad, y el Museo de South Kensington en Londres, dispuso una cantidad para intentar la adquisición de las que, a juicio de sus expertos, eran las más interesantes. Adquiridas por su corresponsal, el especialista Sr. Riaño, parte de esas joyas se pueden contemplar en la sala fuerte del citado museo, hoy denominado Victoria y Alberto ${ }^{31}$. Algunas de estas descripciones son las siguientes: "Una sirena de oro esmaltado con cinco colgantes"; "Una cifra de oro con una palma y corona", una joya "de oro esmaltado con la figura de un manto de N. ${ }^{a}$. $^{a}$ guarnecido con diamantes tabla" ${ }^{32}$; "un papagayo de oro esmaltado de verde, pendiente de dos cadenitas de oro y colgantes de perlas" ${ }^{33}$, similar al dibujado en el códice de Guadalupe; «un perro con una cestita de oro con esmeraldas y bermelletas", "otro perrito de oro esmaltado con diamantes, bermelletas y perlas colgantes" ${ }^{34}$, "un relicario figura de corazon guarnecido de oro esmaltado con la cifra del Nombre del Señor ${ }^{35}$; diversos retablitos de oro con la Virgen del Pilar y otras figuras, con o sin doseles, piedras diversas o perlas ${ }^{36}$. En fin, numerosas alhajas son cita-

29 Ver Letizia ARBETETA MIRA, "Alhajas", en Jocalias para un aniversario (Zaragoza, 1995), nn. 42, 43, 46, 48, 50.

30 Sin signatura ni referencia alguna, lo descubrimos casualmente en el interior de un tomo de actas capitulares. Archivo del Pilar y de la Seo, Zaragoza.

31 Véase, para lo relacionado con las alhajas procedentes del Pilar, hoy en el museo Victoria y Alberto de Londres: Charles Oman, "The Jewels of Our Lady of the Pillar at Saragossa", Apollo, junio (1967), pp. 400-406.

32 Charles OMAN, op. cit., p. 404 , il. 4 y lám. II,c, respectivamente. La primera pieza, de hacia 1630-50, ejemplar típico de las labores llamadas "de engastería", es modelo derivado de los hábitos de la Inquisición, con la cruz flanqueada por palmas, motivo que se repite en otras piezas del Pilar (Letizia ARBETETA Mira, op. cit., núm. cat. 45).

33 Charles OMAN, op. cit., lám. II,e.

3 . Charles Oman, op. cit., lám. II,b,f. Los publica como obra barcelonesa (posiblemente por su parecido con los dibujos de los libros de Pasantías) de hacia 1610.

35 Charles Oman, op. cit., il. 4, p. 404. Este autor lo considera labor de hacia 1630.

36 Sobre los "retablitos", algunos fueron adquiridos para el museo South Kensington, como el de la Virgen del Pilar entre ángeles, muy similar a otro del joyero [Charles OMAN, op. cit., lám. III,b]; Eduardo TORRA DE ARANA, Museo Pilarista (Zaragoza s.a), p. 10; FederiCo TORRALBA SORIANO, "Notas acerca del joyero de la Virgen del Pilar", Revista de la Universidad Complutense, 86 (Madrid, 1973), p. 17; José Manuel CRUZ VALDOvinOS, "Platería y joyería votivas", El Pilar de Zaragoza (Zaragoza, 1984), p. 356, sólo il.; Letizia ARBETETA MirA, op. cit., pp. 210-213. Charles OMAN, op. cit. (lám. III,c), publica otro con la Inmaculada Concepción, que no tiene similar entre lo expuesto del joyero. 


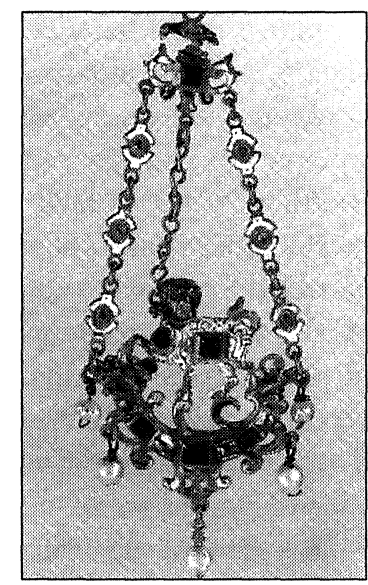

FIG. 8.-Brinco con perrillo en oro esmaltado, con perlas y piedras. Este pinjante fue adquirido por el Museo South Kensington (actual Victoria y Alberto), junto con un extenso lote de joyas vendidas en 1870 .

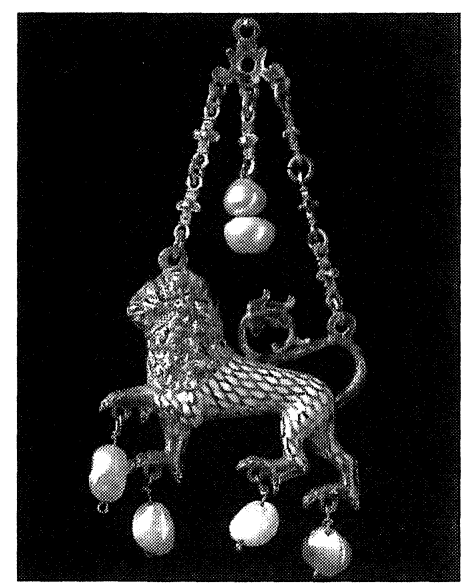

FIG. 9.-Brinco de león pasante. Fueron numerosos los pinjantes de cadenas en el joyero del Pilar, fechables entre 1590 y 1610 , con animales simbólicos realizados en oro esmaltado, a veces enriquecidos con pedrería y perlas, como este león que aún se conserva.

das, entre las que destaca una soberbia pieza consistente en "Un ramo esmaltado con lazo azul" ofrenda de D. ${ }^{a}$ Juana Rabasa, mujer de un ministro de Hacienda de Carlos III ${ }^{37}$, estrella de la colección londinense, y la no menos importante "granada de oro", que fue adquirida en Zaragoza. El inventario permite desechar algunas de las tradiciones acerca de los donantes de las piezas, caso de la paloma cuya donación se atribuye a Amadeo de Saboya, siendo así que consta en el joyel antes de su reinado ${ }^{38}$. También aporta datos a favor de la autenticidad de ciertas piezas, tenidas hoy como dudosas, como los pinjantes con perrillos, que especialistas ingleses sospechan puedan ser copias historicistas basadas en los dibujos de Passanties, ya que existen dibujos preparatorios del célebre imitador de orfebrería renacentista Reinhold Vasters ${ }^{39}$ (Figs. 8 y 9).

37 Charles OMAN, op. cit., p. 402

38 Cf., Letizia ARBETETA MIRA, op. cit., pp. 208-209. Ha venido figurando bajo este epígrafe en el Museo Pilarista.

39 Cf., Mark JONES, et al., Fake? The Art of deception (Londres, 1990), pp. 202-204. Catálogo de la exposición sobre el mismo tema, celebrada en el Museo Victoria y Alberto. 
Otras joyas que se describen pueden contemplarse en el llamado "Museo Pilarista", instalado en el interior de la Basílica ${ }^{40}$. Allí encontramos, por ejemplo, el "librito de rezo de $\mathrm{N} .^{a}{ }^{\mathrm{S}} .{ }^{a}$ con sus cubiertas de relieve de plata" ${ }^{41}$, un "par de pendientes guarnecidos de brillantes" ${ }^{42}$ o la joya "de oro ovalada de N. ${ }^{a}$ S. $^{a}$ con perlas" ${ }^{43}$. Otras se han perdido, y no es fácil averiguar su aspecto ni su época a tenor de las descripciones, como el urelicario de cristal de roca de N. ${ }^{a}$ S. $^{a}$ y el Niño, guarnecido por sus cantos de oro y algunas perlitas", que pudiera ser uno de los que, procedentes del Pilar, se exhiben en Londres ${ }^{44}$, todos de hacia 1600 , parte de una larga serie de ejemplares con marco oval de cristal con cantoneras de oro esmaltado, y a veces, perlas pinjantes, obras de probable origen lombardo para el mercado español. Se añade el "girasol [ópalo] puesto sobre dos serpientes en tembleque, de oro y filigrana, con unos ramitos de brillantes", el "gabilan de oro pendiente de una cadena"; la "palomita puesta en una ahuja con diamantes, rubies y esmeraldas", quizás uno de los diversos clavos, airones o piochas para el cabello, relacionados por su pedrería, de los que se subastaron gran cantidad en 1870 y de los que hoy se conocen escasísimos ejemplares, o un "collar compuesto por trece botones con diamantes tabla que guarnecen las piezas". Por el contrario, piezas que se conservan en el joyero, tan espectaculares, y algo dudosas, como la de Jonás y la ballena, en oro esmaltado y berruecos, o el pinjante del delfín (del tipo que Müller creía figuraciones de orcas), no son citados, aunque el pinjante del lagartillo tampoco se relaciona y, a nuestro entender, es pieza original de principios del s. XVII, posiblemente peruana, combinada con una rosa de esmeraldas algo más tardía y alfiler adaptado. Todas estas joyas se

10 Del contenido de este museo existe un folleto-guía, ya citado, realizado por el Canónigo D. Eduardo TORRA DE ARANA; posteriormente, el Prof. José Manuel CRUZ VALDOVINOS, en su artículo también citado, realizó una enumeración de buena parte de las piezas, agrupadas estilísticamente, con breves comentarios acerca de las más importantes. Hemos realizado una catalogación parcial para el catálogo Jocalias para un aniversario.

41 Llamado comúmente Libro de horas de Santa Isabel de Portugal, denominación tradicional que pudiera ser inexacta. Su labor de platería es datable en la primera mitad del s. XVI, cf. Ángel SAN VICENTE, La platería de Zaragoza en el Bajo Renacimiento (Zaragoza), 1976, I, p. 359; José Manuel Cruz Valdovinos, op. cit., pp. 352, 363, ils. 294-296; Letizia ARBETETA MIRA, op. cit., pp. 40-41.

12 Letizia ARBETETA MiRA, op. cit., pp. 234-237.

13 Creemos que es la misma pieza que describe José Manuel Cruz Valdovinos, con N. ${ }^{a}$ S. ${ }^{a}$ del Pilar y los Apóstoles, con cerco de filigrana de oro cargado de aljófares. Cfr., José Manuel Cruz Valdovinos, op. cit., p. 358.

i Charles Oman, op. cit., p. 402, il. 1. 
usaron prendidas sobre el manto de la imagen titular, pequeña talla en madera dorada de $38 \mathrm{cms}$. de alzada, que fue presentada a la devoción de los fieles, sobre la columna de la aparición, cubierta a la altura de los hombros por un manto, de forma que sólo quedaban visibles las cabezas de la Virgen y el Niño que porta. Posteriormente se bajó el manto hasta la cintura, a modo de gran saya acampanada que cubría parte de la columna, y hoy puede verse la imagen exenta, con el manto a sus pies, sobre la columna, sin los cintillos, mazos de perlas y joyería diversa que antaño llevaba prendidos y cuyo uso consta documental e iconográficamente ${ }^{45}$. El museo cuenta, además, con una gran colección de joyas de finales del siglo XIX y principios del actual, que incluye donaciones diversas de personalidades y realeza, por ejemplo el ramo de plata y brillantes que se exhibe como donado por la reina Victoria Eugenia en acción de gracias tras el atentado de Mateo Morral; un bastón con la cifra de Alfonso XII en el puño; la diadema filipina que regaló Doña Sofía, reina de España, y otros muchos donativos de diferentes personajes, para cuyo conocimiento remitimos a las obras citadas en la nota núm. 36.

\section{El Catálogo de la subasta de $1870^{46}$}

Desde 1863 se hallaban en curso obras de finalización de la Basílica, en las que se habían invertido más de diez millones de reales; para impedir su interrupción al haber agotado los recursos, se ofreció en pública subasta un extenso conjunto de la colección de alhajas existentes en el joyero de la Santa Capilla ${ }^{47}$. El catálogo, del que Charles Oman ${ }^{48}$ opina que es inadecuado, pero no excesivamente malo, constituye un documento valiosísimo para reconstruir cómo era un joyero mariano de gran importancia a mediados del siglo xIX. Veremos que, al igual que en Guadalupe,

45 Véase el artículo de Francisco BORRÀs Girona y José M." BORDETAS AlOnSO, "Los mantos de la Virgen", El Pilar de Zaragoza (Zaragoza, 1984), pp. 57-76; y con carácter general, el resto de la citada publicación, así como el catálogo de la exposición El Pilar es la Columna (Zaragoza, 1995).

46 Catálogo de las albajas de la Santísima Virgen del Pilar de Zaragoza que con la debida autorización se enagenan en pública subasta para la continuación de las obras del mismo Santo Templo Metropolitano (Zaragoza, 1870, sin autor).

47 El Cabildo sopesó la selección de alhajas, y, según consta en el libro de Actas Capitulares correspondiente a 1870 , se redactó una lista reservando aquellas consideradas singulares o más importantes, muchas de las cuales aún podemos contemplar.

48 Véase, sobre la venta de 1870 y las adquisiciones del museo de South Kensigton: Charles OMAN, op. cit. 
abundan las donaciones atribuidas a grandes personajes, joyería de subido valor artístico, y - lo que es más importante- se recoge también una serie de humildísimos exvotos.

Curiosamente, este singular documento no ha sido estudiado en profundidad. Aunque el espacio del que disponemos no nos permite extendernos como merece, indicaremos al menos lo más notable de su contenido.

Se subastaron piezas vinculadas a personalidades históricas -algunas bien documentadas por Ignacio Miró, especialista en el tema, con el consejo del Barón Charles Davillier, asimismo conocedor de la orfebrería española- como la espada historicista que Isabel II entregó en 1860 (núm. 2 del catálogo); un collar donado por María Luisa de Parma (núm. 3), un medallón con brillantes y retrato de Fernando VII, ofrecido a su regreso de Francia en 1814 (núm. 6); las agujas de cabeza con brillantes que fueron de María Cristina de Borbón (núm. 11); la placa de la Orden del Espíritu Santo que entregó M. ${ }^{a}$ Teresa Vallabriga, modelo de Goya y esposa del Infante Don Luis (núm. 1); la diadema regalada por la esposa del Infante Don Sebastián de Borbón (núm. 32), y el aderezo de coral que entregó éste en 1868 , del que parte creemos se dispuso en el sobrehalo de la corona rica (núm. 216). Más populares, y quizás entregadas con carácter de exvoto serían los toros núms. 519 y 520, regalo, respectivamente, de los célebres toreros Curro Cúchares y Pepe Hillo. Un toro de plata, ofrecido por Cúchares en 1839, que se encuentra en el Museo, podría ser la misma pieza citada en el catálogo, pues algunos objetos, una vez subastados, fueron devueltos al joyero por sus compradores.

Es tradicional la identificación de una ofrenda de Felipe IV con un reloj de cuerda de guitarra y tapas caladas enriquecidas con diamantes, subastado con el núm. 437.

Aunque anónimo, debió ser encargado ex profeso para ser entregado al Pilar el lazo con un manto de la Virgen que hoy se conserva en el Museo Victoria y Alberto de Londres (núm. 120) ${ }^{49}$, ofrendado en 1678 por el marqués de Navarens, alhaja que Oman considera francesa, pero de la que no conocemos paralelos para verificarlo.

Sin duda, la necesidad de dinero era perentoria y la cantidad deseada la mayor posible, porque se subastaron también piezas humildes de la piedad popular, como la colección de cabezas, pies, piernas, ojos, bustos, corazones y dedos de plata que se relacionan (núms. 356 y ss., etc.), junto con rosarios diversos de plata, e incluso alguno de latón (s46), tumbagas, sortijas con trenza de pelo (núms. 326 y 327), condecoraciones, abanicos de filigrana oriental, dijeros, chupadores (núms. 411, 412...), medallas, cruces y numerosas imágenes de la propia Virgen del Pilar en plata, como las

49 Charles OMAN, op. cit., p. 404, lám. II,c. 


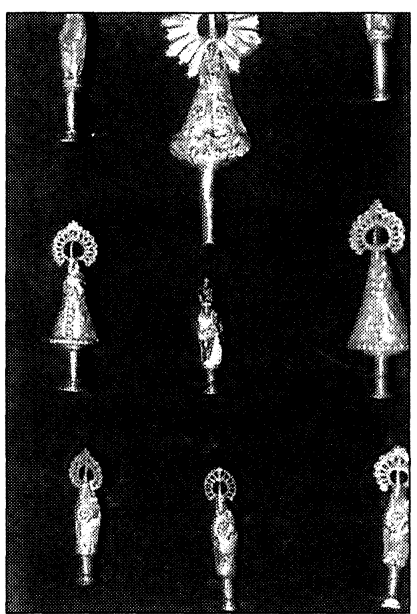

FIG. 10.-En el Museo Pilarista aún se pueden ver diversas imágenes de la advocación titular que recuerdan los exvotos tradicionales que la basílica poseyó en gran número. que se exponen en el Museo Pilarista, todo ello de escaso valor material (Fig. 10).

Bajo el epígrafe de "Alhajas artísticas", se describen aquellas que se consideran más valiosas según el concepto artístico de la época: la admiración por Rafael se trasluce en la descripción de la alhaja núm. 435, y no falta la adscripción a Benvenuto Cellini de algunas piezas de la colección, en este caso la granada núm. 433, o el relicario núm. 451.

Abundan en el catálogo las descripciones de los brincos o pinjantes de cadenas, esmaltados y enriquecidos con pedrería y perlas, a veces colgando, con figuras de animales o seres fabulosos, como el ciervo con el cuerpo formado por una perla (núm. 444), al igual que sucede con un conejo (núm. 446); una lamia y una sirena, las dos esmaltadas, la primera con gran berrueco (núms. 445 y 447), un papagayo con un jacinto en la pechuga (núm. 450), llevado también a Londres, como dos de los varios perritos (núms. 436, con cuatro cadenas, sobre un cojín, 441, 449), que ya se han citado.

Otros ejemplos de animalística son las águilas, como las núms. 452 y 453 , la primera con esmeraldas y la segunda con perlas ${ }^{50}$, o el pelícano con un granate en el pecho (núm. 442) ${ }^{51}$. Continúa una extensa relación de cruces de oro esmaltadas, con cristales de roca o diversas piedras, y de cruces de cristal con cabos de oro esmaltado, que, si son similares a las que conocemos, tanto en Londres como Zaragoza, hubieron de ser piezas de gran interés. Alternan descripciones de las diferentes representaciones de N. ${ }^{a}$ S. ${ }^{a}$ del Pilar, bien en bulto redondo, bien en bajorrelieve, aplicadas o no sobre fondo de plancha calada, esmaltada y enriquecidas con perlas y piedras.

Entre las tipologías comunes, constan, aisladas, algunas joyas singulares, como la 460 "Un camafeo que contiene el busto de la Virgen en relieve y cuya materia es sardónica oriental guarnecida de oro cincelado. Siglo XVIn, descripción que nos recuerda ciertas obras de la glíptica italiana; la 508

50 Quizás sea ésta la que publica Joan Evans, A History of Jewellery 1100-1870 (Nueva York, 1970), la lám. 10.

51 Charles OMAN, op. cit., p. 401, lám. II,a. 
"Corazón de cristal de roca con la montura de oro"; la 510 "Una mano asiendo un racimo de ubas formado con perlas y montado sobre oro esmaltado" 52 .

En la parte general se describen joyas que no han de ser menos importantes, y algunas que sentimos no identificar por las aportaciones que hacen al vocabulario de la platería de oro española. Por ejemplo, el núm. 12, par de pendientes llamados de manto, época de Carlos III, que suponemos sean los denominados girandole; los tan citados cintillos del Barroco (núm. 27); los bajos de pendientes del núm. 104, de diamantes sobre plata. Resulta difícil saber a qué corresponden exactamente descripciones tan confusas como las núm. 177 (joya) o 178 ("gran pieza de oro con esmeraldas"), quizás un peto.

\section{LAS CORONAS}

Mención aparte merece el conjunto de coronas de la Virgen, realizadas casi todas en oro, que incluye piezas capitales para la historia de la platería de oro en España. Como sucede con las joyas, sus estudios son escasísimos, citándose de pasada al mencionar otras piezas existentes en la sacristía del $\mathrm{Pi}$ lar ${ }^{53}$; sobresale una corona manierista, de extraordinaria calidad, fechada en 1583, obra de Alonso de Rebiras o Ribera, donada por un miembro de la familia Zaporta, posiblemente Gabriel Zaporta, banquero de Carlos V, como parece indicar la escueta anotación del inventario de $1873^{54}$. Otra, fechada en 1645 (Fig. 11), y sobre todo una, a la

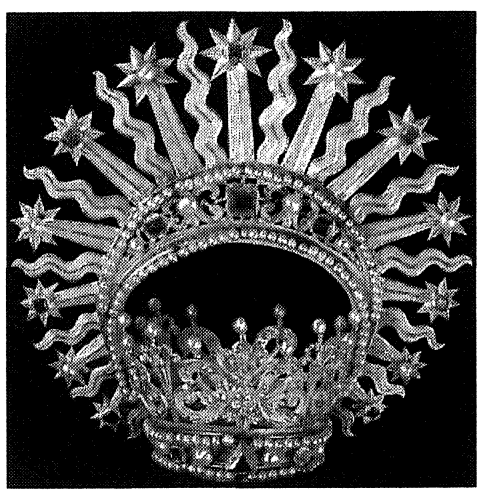

FIG. 11.-Corona de oro, perlas y piedras, fechada en 1645, obra de exquisita factura y excelentes proporciones, siguiendo modelos aragoneses. Museo Pilarista.

52 Ibid., p. 404.

53 Casi todas las coronas que se exponen en el Museo Pilarista son descritas, y algunas comentadas, por José Manuel Cruz Valdovinos (op. cit.). Posteriormente, para la exposición Jocalias, son catalogadas tres de ellas (Letizia ARBETETA MirA, op. cit.), pp. 196, 197, 202-206, 228-229, núms. 41, 42 y 43). Finalmente, hemos estudiado el conjunto de coronas y halos realizados por la firma Ansorena con ocasión de la Coronación Canónica de la Imagen: Letizia ARBETETA MIRA, "Orfebrería religiosa", Ansorena. 150 años en la joyería madrileña (Madrid, 1995), pp. 72-80.

54 José Manuel Cruz Valdovinos, op. cit., p. 323; cfr., Letizia Arbeteta Mira, op. cit., pp. 202-207. 
que apenas se ha prestado atención, que se describe como "corona bizantina" o "del estilo del Renacimiento", que, pese a haberla examinado atentamente, no podemos clasificar con precisión, pues su cestillo o coronel parece antiguo, así como algunas de sus partes, posiblemente deformadas por una manipulación historicista ${ }^{55}$, que enmascara el aspecto original de la pieza. De hecho, aparece en los inventarios la descripción de la cruz que la remata, de cristal de roca y oro esmaltado, similar a otra del Museo, así como el racimo de perlas que cuelga de los imperiales, sujeto, al igual que varias perlas, por flores de oro esmaltado que parecen obra de la segunda mitad del siglo xvil. Sin embargo, el motivo mixto de jarras y candelieri, que alterna con los rayos del halo, parece, cuanto menos, extraño. Los esmaltes también tienen un aspecto demasiado nuevo, con pocas pérdidas, pero han podido ser repuestos. Los mismos imperiales son posteriores al estilo que presenta la corona, cuyo reverso parece, sin embargo, confirmar que se trata de labor antigua. En realidad, no se conocen apenas ejemplares de la platería de oro de la época de Carlos V, y esta corona podría aportar datos hoy desconocidos. En cualquier caso, el diseño del canastillo sigue modelos renacentistas, con el motivo de los delfines atados por la cola, cornueopias, cresterías y urnas, todo ello desarrollado en una complicada estructura calada, de oro picado de lustre, con esmaltes embutidos y a la gota.

Las partes que consideramos genuinas podrían datarse como del primer tercio del siglo XVI, basándonos en los dibujos de pasantías o exámenes de maestría del gremio de plateros de Barcelona; en su tomo primero, comenzado a principios del siglo XVI, encontramos, en una serie de dibujos inéditos, algunos motivos similares, que remiten a una moda concreta. Así, el dibujo núm. 66 presenta igual diseño de urnas gallonadas en el vientre, cuerpo cóncavo estriado y tapa levemente abombada; el núm. 78, fechado en 1522, muestra idénticas cornucopias que surgen del rótulo con la fecha, labores de roleos y, en la base, elementos turriformes de cardinas, que recuerdan la superposición de jarras con el mismo cuerpo que las urnas. Hacia 1531 se realizó el dibujo núm. 92, obra de Honorat Collteller, con similar dibujo de urna, y la presencia de dos delfines. No hay que olvidar que cada una de estas coronas, así como las que no se citan en este artículo, tuvieron, o tienen su correspondiente coronita a juego para la diminuta cabeza del Niño Jesús que lleva la Virgen en brazos. En la mayoría de los casos, estos conjuntos están descabalados, sobreviviendo alguna coronita antigua, como la de hacia 1500, que estudiamos en 1995, mientras que en otros sólo se conserva la corona mayor. Por ello

55 Ver Letizia ARBETETA MirA, "Alhajas», p. 196, nota núm. 9. 
es de destacar el caso de una corona barroca, con el halo en media luna calada con roleos y resplandor de flamas con estrellas al tope y rayos alternos, según modelo común al área mediterránea, y corona con imperiales y canastillo prolijamente elaborados, toda cargada de perlas y esmeraldas, que conserva la corona del Niño a juego, un simple canastillo, también con esmeraldas y perlas.

Existe otro juego completo, regalo de los marqueses de Casa-Madrid, núm. 3 del inventario del joyero y 95 y 101 del inventario de $1873^{56}$.

Es imposible enumerar todas las piezas que están actualmente expuestas, pero sí procede detenerse ante el conjunto más conocido de todas las alhajas del Pilar: las coronas, halo y sobrehalo que la Casa Ansorena de Madrid realizó en 1905 para la coronación canónica de la imagen titular. Nos remitimos, para el estudio técni-

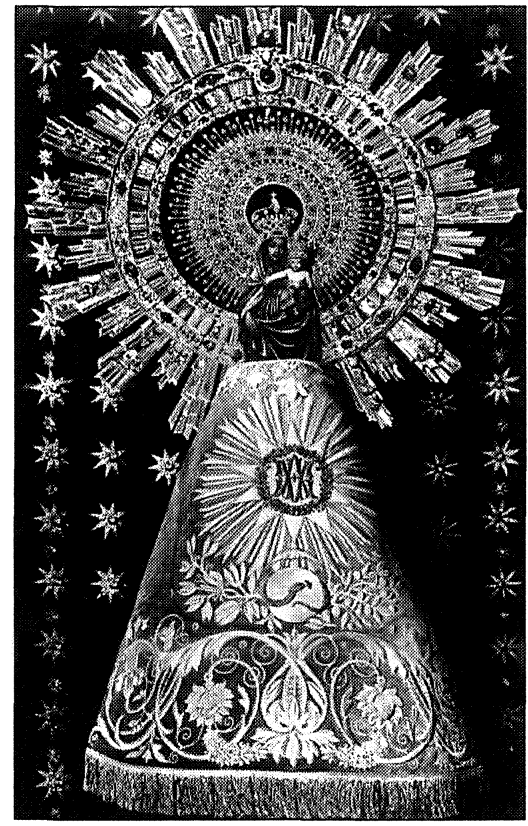

FIG. 12.-Obra de la firma Ansorena, la más célebre de las coronas españolas fue realizada en 1905 y ha vinculado su imagen a la iconografía habitual de N. ${ }^{a}$ S. ${ }^{a}$ del Pilar. co de las piezas, así como las incidencias de la ceremonia de la Coronación, a nuestro trabajo recientemente publicado ${ }^{57}$, por lo que centramos nuestra atención en las alhajas donadas para la realización de las coronas (Fig. 12).

Como sabemos, se realizó una campaña nacional de donación de alhajas, que debían recoger las Juntas Provinciales encargadas de organizar la peregrinación nacional a Zaragoza.

Magaña, cronista de los actos de $1905^{58}$, ofrecía la relación de las alhajas recogidas por la Junta de Zaragoza, añadiendo que lo obtenido en las demás provincias sería en breve publicado por la Junta Central, coordinadora de las juntas provinciales. Parece ser que no fue así, y el

\footnotetext{
56 Inventario del Sto. Templo Metropolitano de Ntra. Sra. del Pilar año de 1873 (Zaragoza, Archivo del Pilar y de la Seo, I-40).

57 Véase nota 53.

58 A Magaña, La Virgen del Pilar. Coronación y peregrinación 1905 (Zaragoza, 1905).
} 
resultado de la campaña quedó inédito. Sin embargo, todas las alhajas fueron entregadas, debidamente inventariadas, a la Casa Ansorena, firma de joyeros encargada de realizar las coronas ${ }^{59}$. Ya se dio cuenta, en el estudio citado, de varias donaciones importantes y piezas antiguas que se habían colocado sin deshacer en el sobrehalo de oro que enmarcaría las coronas y halo cuajados de pedrería. Sorprendía, en primer lugar, la diversidad de objetos de plata que se reunieron para ser fundidos: vasos, servilleteros, cubiertos, monedas, alguna escribanía, monturas de anteojos, pedazos de cadenas, relojes, petacas, puños de bastones, cajitas, tazas, portamonedas, dedales, etc. ${ }^{60}$ Alguno de estos objetos podía tener valor artístico, por ejemplo, el descrito en el núm. 962, “caja para rapé en oro y esmalten.

Algún detalle humano se deja entrever en la escueta relación, como el anillo arrojado por la verja de la santa Capilla, los útiles de fumador entregados por el párroco de Villanueva, las alhajitas que unos nietos donan en memoria de su abuelo, etc.

En principio, se entregaban las alhajas a la Junta, pero, a veces, los párrocos, obispos o la prensa local sirvieron de mediadores; se consignan colectivamente los objetos reunidos como resultados de la cuestación en poblaciones de Aragón y otros muchos lugares grandes y pequeños: Talavera de la Reina en Toledo, Fuentes del Maestre, Vitoria, Medina Sidonia, Sevilla, o Écija ${ }^{61}$, pueden servir de muestra. Aunque algunas juntas recogen puntualmente el nombre de cada donante, lo que incluye casi toda la nobleza, también abundan las indicaciones anónimas. Son frecuentes las expresiones: "una persona piadosa", "un devoto", "una devota", a veces adjetivado: "tres señoritas devotas ${ }^{62}$, "una señora devota", "un matrimonio piadoso", "una Hija de María" y, más especificamente, referencias al periódico que colaboró en la campaña, El Universo; así, encontramos en varias ocasiones que algunos donantes anónimos se identifican como suscriptores del diario. Otros datos, aunque anónimos, se refieren a la situación concreta del donante: "un artillero retirado" ${ }^{63}$.

59 Véase Letizia ARBETETA MirA, op. cit., pp. 71-81.

60 Corresponden a estos ejemplos los asientos núms. 124, 138, 197, 359, 697, 700, 812, 1009 de la relación general y 43 y 66 de la relación de Zaragoza. Datos, al igual que las notas siguientes, extraídos del manuscrito: Albajas entregadas al Sr. Ansorena por las Excmas. Sras. Marquesas Viuda de Aguilafuente y Condesa Viuda de Torrejón para la corona de la Virgen del Pilar de Zaragoza (Madrid, 1905), s.l. ni a.

61 Ejemplos en los núms. 110, 177, 239, 243, 1097, así como en los núms. 853, 1019, 1075, 1106, 1116, 1118, 1119 del manuscrito Alhajas entregadas... ya citado.

62 A. MAGAÑA, op. cit., p. 11.

63 Corresponden a estas denominaciones los núms. 28, 38, 98, 110, 178, 240 y 1030 de la relación general. 
El contenido de la relación no es menos interesante, pues, en primer lugar, proporciona datos sobre las alhajas de las que disponían los españoles a principios de siglo, y sobre todo lo que estaban dispuestos a ofrecer. Aunque no se acompañan valoraciones, es de suponer que las damas aristocráticas que formaban parte de las diversas juntas encabezaron las suscripciones con valiosas alhajas. Muchas, en vista de que las joyas iban a ser fundidas y sus piedras desmontadas para acoplarlas al diseño aprobado, prefirieron entregar piedras sueltas: brillantes, algunos muy grandes, encabezados por el donado por la Reina María Cristina, perlas, piedras finas con tonalidades de moda, como topacios, amatistas, granates... ${ }^{64}$

Se donaron muchas monedas de oro y plata, la mayoría antiguas, cuyo destino era el crisol: monedas romanas, americanas, de diferentes reinados, a veces especificados y a veces no: "onzas de oro", "duros antiguos", "duros mejicanos", de 1784, de 1809, 1867, de Fernando VII, Alfonso XII, libras esterlinas, coronas de oro, etc ${ }^{65}$. Entre las alhajas entregadas se reconocen modelos propios de la joyería decimonónica: brazaletes esmaltados, camafeos, alhajas con cifras o letras, como las sortijas "recuerdo" ${ }^{66}$; estrellas de diamantes y brillantes, mediaslunas, brazaletes diversos y broches con diseños de culebras, medallones con miniaturas, guardapelos, aderezos y medios aderezos realizados con turquesas, perlas, amatistas, ópalos, granates, etc. ${ }^{67}$

A la moda del momento corresponden los diseños trèfle, o trébol, consistentes en disponer las piedras triangularmente, que se usaba en bro-

64 Sirvan de ejemplo los siguientes números: 3-Perla gris en forma de perilla, Marquesa de Almaguer; 5-Topacio tostado, Marquesa de Bárboles; 6-Brillante (Junta central), Marquesa de Mirasol; 180, otro brillante, Marquesa de Rafol; 45-Amatista grande, Duques de la Conquista; 193-Dos granates, Condesa de Sepúlveda; 258-Un brillante grande, tasado en 1008 ptas de la Congregación Josefina de Familias Cristianas; 330topacio grande, Duquesa de Noblejas; 113-Dieciseis brillantes, Marquesa de Moctezuma...

65 Núms. 112, 148, 630, 631, 632, 634, 635, 671, 1011, 1081, 1083, etc.

66 Núm. 22 de la relación de Zaragoza: Sortija de oro con inscripción "recuerdo".

67 Se pueden citar al respecto los siguientes números: 2-Medallón de ónix con estrellas de diamantes; 12-Broche trèfle de brillantes y tres turquesas; 22-Pulsera de oro con una culebra con diamantes; 24-Estrella de brillantes; 79-Media luna de brillantes y zafiros; 106-Brazalete de oro con ópalos; 167-Alfiler de corbata trèfle con dos brillantes y una perla; 175-Medallón de oro con miniatura; 212-Brazalete de oro con nombre en esmalte; 220-id. con camafeos; 252-Estrella de brillantes; 17-Relación de Zaragoza-Pulsera con ópalo; 833-Broche culebra con esmalte, diamantes y brillante perilla; 1040-Estrella de ocho radios. Centro y orla de brillantes; 1099-Alfiler de ópalos, etc. En cuanto a la descripción de aderezos, núms. 177-Aderezo de pulsera, broche, pendientes; 33 de Zaragoza-Aderezo: pulsera, alfiler, pendientes, etc. 
ches y especialmente alfileres de corbata, gemelos, sortijas y otras menudas alhajas masculinas, que también se entregan, como botonaduras y botones de pechera con pedrería diversa ${ }^{68}$. Eran muy apreciados desde la segunda mitad del siglo XIX los collares de brillantes dispuestos en rivière o hilera, como los célebres de chatones, alhajas de gran precio, que igualmente se encuentran en el listado ${ }^{69}$, así como las flores y ramos de brillantes ${ }^{70}$. Sin embargo, otros modelos, como la pulsera "Fe, Esperanza y Caridad" del núm. 1125, o el "pensamiento" núm. 659, con amatistas, recuerdan diseños de la década final del s. XIX.

Otras de las joyas entregadas se consignan como antiguas, pero sin acompañarse de ninguna descripción, lo que permite suponer que algunas podrían ser anteriores al siglo XIX, ya que los modelos de este siglo, como hemos visto, aún estaban en uso: pendientes, alfileres, lazos, broches, medallones, sortijas, algunas del tipo denominado "lanzadera" por la forma del chatón, de moda desde el s. XVIII ${ }^{71}$. Curiosamente, ninguna de las que han sobrevivido dispuestas en el sobrehalo se menciona entre las antiguas. También tenían pleno uso joyas indicativas del rango social, como los broches en forma de corona, las condecoraciones o los lazos de Dama otorgados por las reinas españolas, así como anillos pastorales ${ }^{72}$. Por contraste, se mencionan también joyas más modestas, seguramente populares, como pendientes de coral, collares de aljófar, medallas antiguas de plata, labores diversas realizadas en filigrana de plata y oro ${ }^{73}$.

68 Núms. 38-Botonadura de oro y brillantes; 298-Gemelos de monedas de oro; 72 y 73 de la relación de Zaragoza: Dos botones de pechera de brillantes; botonadura de oro y granates; etc.

69 Núm. 222-Collar rivière de brillantes, donado por la Marquesa de Pidal.

70 Ej. núm. 151.

71 Núms. 180-Alfiler antiguo de oro y esmalte; 305-Sortija antigua; 348-Pendientes antiguos de oro y diamantes; 13 de la relac. de Zaragoza-Alhaja antigua de oro y diamantes; 33-Sortija antigua con diamantes; 157-alfiler antiguo de oro y esmeraldas; 595-Sortija antigua de oro y brillantes; 1092-Sortija antigua con diamantes, etc. Quizás fuea antiguo también el núm. 1116: Dije en forma de libro.

72 Núms. 78-Insignia de Dama, brillantes, zafiros, cedida por la Marquesa de Miraflores; 90-Inicial y corona de zafiros y brillantes; 117-Una corona-broche de perlas, esmeraldas, brillantes, de la Condesa de Mejorada del Campo; 367-Corona de marquesa; 25 y 97 de la relac. de Zaragoza-Corona de Marquesa; anillo pastoral; 132- Siete condecoraciones militares; 669-Anillo de topacio, Sr. Obispo; 1134-Cruz Carlos III; etc.

73 Núms. 321-Ocho medallas antiguas de plata; 359-pendientes de filigrana; 43Alfiler de plata peruana; 101-Medallón antiguo y dos lazos de oro y piedras, del pueblo de Mainar; 589-Cruz de filigrana de plata; 785-Medalla de filigrana; 1106- 3 rosarios, medios aderezos, alguno de filigrana, etc. 
Por último, sólo resta constatar que se entregaron varias efigies de la propia Virgen del Pilar, incluso alhajas con este nombre, lo que podría señalar la intención, por parte de los donantes, de lograr una coherencia absoluta entre la materia misma de la ofrenda y el fin a que se dedicaban las coronas.

En definitiva, esperamos que este breve recorrido por la historia de estos importantes joyeros marianos sirva para mostrar el interés que este tipo de manifestaciones piadosas tiene para el estudio de la historia de la platería de oro española, apenas conocida ${ }^{74}$, y para un mejor conocimiento de la religiosidad popular en nuestro país.

LETIZIA ARBETETA Mira

Ministerio de Educación y Cultura

La costumbre de ofrecer joyas como exvoto, especialmente a las imágenes marianas, ha dado origen a la acumulación de auténticos tesoros en los santuarios. Se analiza aquí cómo nacen, se acrecientan, menguan y mueren estos conjuntos, tomando como ejemplos los santuarios de Guadalupe (Cáceres) y el Pilar de Zaragoza. Se demuestra cómo, una vez más, la Antropología aporta elementos que no debe desdeñar la Historia del Arte, además de constituir un material de primer orden para el estudio de la joyería hispánica, al incluir piezas tanto peninsulares como coloniales.

The custom of offering jewels to representations of the sacred beings of Roman Catholicism, specially to statues of Mary, has resulted in the accumulation of truly artistic treasures in Spain's churches and shrines. The author examines the way these offerings begin, grow, wane, and die out by taking as instances those found at the shrines of Our Lady of Guadalupe (Caceres) and Our Lady of the Pillar (Saragossa). Besides calling attention to a body of first rate material for the study of Spanish jewelry - material which comes from Spain's colonies as well as from the mainland-, the paper shows, like many others, how an anthropological approach can come up with insights that art historians can only ignore at their peril.

71 La única obra general que hasta la fecha existe sobre el tema es el trabajo de Priscilla MÜLleR, Jewels in Spain 1500-1800 (Nueva York, 1972). El importante estudio, aunque proporciona una ingente cantidad de noticias, datos documentales y visuales sobre la joyería de cada época, carece de estructura y no aclara las tipologías ni la evolución de los modelos, con dataciones concretas. 